\title{
PENGARUH MODAL KERJA DAN BIAYA OPERASIONAL TERHADAP PROFITABILITAS
}

\author{
Ani Widosari Trisnaningsih ${ }^{1}$, Haryono Umar ${ }^{2}$ \\ ${ }^{1}$ STIE Muhammadiyah Jakarta \\ ${ }^{1}$ STIE Muhammadiyah Jakarta, flamboyan24@ gmail.com
}

\begin{abstract}
ABSTRAK
Dalam Pengambilan suatu keputusan profitabilitas tentunya perusahaan harus mempunyai modal yang cukup guna membiayai operasional pada perusahaan. Hal ini untuk melihat seberapa pengaruh Modal kerja dan Biaya operasional terhadap Profitabilitas. Metode Penelitian yang di gunakan oleh peneliti adalah metode analisis regresi linier berganda, uji koefisien determinasi, dilakukan juga uji asumsi klasi yaitu Uji Normalitas,Multikolinieritas, Heteroskedastisitas dan Autokorelasi dan juga Uji Hipotesis yang terdiri dari Uji F dan Uji t.

Berdasarkan Uji t (secara parsial) dapat diketaahui bahwa modal kerja berpengaruh signifikan terhadap profitabilitas. Sedangkan Untuk Biaya Operasional tidak berpengaru terhadap Profitabilitas. Dan berdasarkan Uji F nilai Fhitung bahwa modal kerja dan biaya operasional berpengaruh terhadap profitabilitas.
\end{abstract}

Kata Kunci : Modal Kerja, Biaya Operasional, dan Profitabilitas

\begin{abstract}
In making a profitability decision, of course the company must have sufficient capital to finance operations in the company. This is to see how the influence of working capital and operational costs on profitability. The research method used by researchers is the method of multiple linear regression analysis, the coefficient of determination test, also performed a classic assumption test that is the Normality, Multicollinearity, Heteroscedasticity and Autocorrelation Tests and also the Hypothesis Test which consists of the F Test and the $t$ Test.

Based on the t test (partially) it can be seen that working capital has a significant effect on profitability. Whereas Operational Costs do not affect the profitability. And based on the F Test the value of Fcalculates that working capital and operational costs affect profitability.
\end{abstract}

Keywords: Working Capital, Operating Costs, and Profitability

\section{PENDAHULUAN}

Pada dasarnya setiap perusahaan atau organisasi akan melakukan berbagai aktivitas untuk mencapai tujuan yang telah di tetapkan perusahaan, pada umumnya adalah untuk memperoleh laba. Pada sisi yang berkaitan dengan perusahaan sebagai pelaku ekonomi yang melakukan aktivitasnya untuk tujuan memperoleh laba yang akan di gunakan bagi kelangsungan hidup (kontiuitas) perusahaan dan pertumbuhan usahanya agar dapat berjalan dengan baik,maka diperlukan sumber-sumber ekonomi yang baik dan kemampuannya dari perusahaan dalam mengelola sumber tersebut.

Modal kerja merupakan masalah pokok dan topik penting yang sering kali dihadapi oleh perusahaan,karena hampir semua perhatian untuk mengelola modal kerja dan aktiva lancar yang merupakan bagian yang cukup besar dari aktiva. Modal kerja dibutuhkan oleh setiap perusahaan untuk membelanjai operasinya sehari-hari,misalnya : Untuk memberikan uang muka pembelian bahan mentah ,membiayai upah pegawai dan lain lain,dimana uang atau dana yang di keluarkan 


\section{JURNAL AKUNTANSI, Vol. 7, No. 2, November (2018)}

tersebut di harapkan dapat kembali lagi masuk dalam perusahaan dalam waktu singkat melalui hasil penjualan produksinya.

Begitu pula kemajuan perusahaan akan seiring dengan kebutuhan modal yang diperlukan untuk membiayai kegiatan usahanya, dimana makin besar suatu perusahaan akan semakin besar pula modal yang di butuhkannya dan tidak mungkin dapat dipenuhi oleh perusahaan sendiri tanpa ada bantuan atau menarik modal dari luar perusahaan.

Menurut Munawir $(2004 ; 124)$ tersedianya modal kerja yang cukup dapat segera dipergunakan dalam operasi tergantung pada tipe atau sifat dari aktiva lancar yang dimiliki perusahaan seperti : kas (surat-surat berharga), piutang dan persediaan. Semakin cepat tingkat masing-masing elemen modal kerja maka modal kerja dapat dikatakan efisien ,tetapi jika perputarannya semakin lambat maka penggunaan modal kerja dalam perusahaan kurang efisien. Tetapi modal kerja cukup jumlahnya dalam arti harus mampu membiayai pengeluaranpengeluaran atau operasi perusahaan sehari-hari,karena dengan modal kerja yang cukup akan menguntungkan bagi perusahaan khususnya dalam memperoleh laba, disamping memungkinkan bagi perusahaan untuk beroperasi secara ekonomis atau efisien dan perusahaan tidak mengalami kesulitan keungan juga akan memberikan beberapa keuntungan lain. Perusahaan sebaiknya menggunakan modal kerja dengan baik untuk mendapatkan profitabilitas yang tinggi,perusahaan sebaiknya menginvestasikan modal kerja sehingga modal kerja tersebut dapat berputar. Dengan menimbulkan pembengkakan modal kerja sehingga akan mengkibatkan kesulitan bagi perusahaan untuk meningkatkan profitabilitas (Pierre,2010). Manajemen atau pengelolaan kerja adalah suatu hal penting untuk kelangsungan dari perusahaan sehingga kedepannya dapat dipertahankan (Hanafi dan Halim 2005:125) .

Jika melakukan kesalahan maka perusahaan akan mengalami kerugian keuangan atau tidak dapat beroperasi sama sekali. Mengingat pentingnya modal kerja dalam perusahaan,manajemen keuangan harus dapat merencanakan dengan baik besarnya jumlah modal kerja yang tepat dan sesuai dengan kebutuhan perusahaan. Hal ini dikarenakan jika terjadi kelebihan atau kekurangan dana dan mempengaruhi tingkat profitabilitas perusahaan. Manajemen belum bisa menjaga keseimbangan perusahaan dalam mengatur siklus perputaran modal kerja,karena di dalam pengelolaan modal kerja itu sendiri ada beberapa kontradiksi yang dialami perusahaan yaitu modal kerja yang menitikberatkan pada usaha untuk menjaga likuiditas dan modal kerja yang menitikberatkan pada usaha untuk mendapatkan profitabilitas.

Modal kerja juga berupa kas dan setara kas persediaan dan piutang jangka pendek . Jika modal kerja dikelola dengan baik,maka perusahaan tidak akan menemukan banyak kesulitan dan hambatan dalam menjalankan aktivitas operasi perusahaan.

Sebaliknya,pengelolaan modal kerja yang tidak tepat akan menyebabkan aktivitas operasi perusahaan terganggu,dan hal ini merupakan sebab utama kegagalan perusahaan dalam mempertahankan kelangsungan hidup dari perusahaan itu sendiri.

Pertumbuhan dan perkembangan perusahaan dewasa ini pada umumnya menunjukan persaingan yang sengit dan kuat,baik itu pada perusahaan industri maupun perusahaan jasa. Banyak perusahaan yang tidak mampu berdiri lama disebabkan oleh ketidakmampuan perusahaan tersebut dalam bersaing dengan perusahan-perusahaan lain yang banyak bermunculan. Hal ini di pengaruhi banyak faktor. Seperti lemahnya kerja sama manusia dalam mengelola sumber-sumber yang tersedia dan biaya operasional ,peranan kepemimpinan yang tidak efektif, serta kecilnya pendapatan perusahaan dibandingkan dengan pengeluarannya.

Untuk menjalankan suatu usaha diperlukan sumber daya atau sumber ekonomis yang harus di korbankan sebagai nilai pengganti untuk memperoleh keuntungn. Sumber daya atau sumber ekonomis yang di ukur dalam satuan uang,yang telah terjadi ,sedang terjadi atau yang kemungkinan akan terjadi untuk tujuan tertentu dimana sumber daya dan sumber ekonomis 
yang di pergunakan sering kali disebut dengan biaya. Menurut Kuswandi (2006:60) Biaya adalah semua pengeluaran untuk mendapatkan barang atau jasa dari pihak ketiga. Dalam hal ini ,biaya adalah uang tunai atau kas atau ekuivalen kass (harta non-kas yang dapat di ukur untuk barang atau jasa yang di inginkan) yang dikorbankan untuk barang atau jasa yang diharapkan dapat memberikan laba baik masa kini maupun masa datang.

Menurut Abrams \& Laplante (2010:218) Operasional adalah bagian yang meliputi insfrastruktur , pelengkapan,proses dan prosedur yang di gunakan sehingga bisa memproduksi dan menyampaikan produk atau jasa dengan satu cara yang memungkinkan ,untuk menjalankan usaha yang menguntungkan. Operasional merupakan aspek yang penting karena tanpanya tidak ada yang bisa dikerjakan.

Sedangkan biaya operasional menurut Jusuf (2007:33) biaya operasional atau biaya usaha (operating expenses) adalah biaya-biaya yang tidak berhubungan langsung dengan produk perusahaan tetapi berkaitan dengan aktivitas operasional perusahaan sehari-hari. Biaya usaha sering disebut juga dengan istilah SGA (Selling,General dan Administrative Expense).

Profitabilitas merupakan kemampuan perusahaan untuk menghasilkan laba. Jika suatu perusahaan mempunyai pembiayann yang besar dalam menjalankan usahanya yang dapat mengakibatkan penurunan laba bersih suatu usaha merupakan faktor penyebab turunnya profitabilitas. Dan dalam hubungannya penjualan,total aktiva maupun modal sendiri sering digunakan untuk mengukur penggunaan modal suatu perusahaan dengan memperbandingkan antara laba dengan modal yang digunakan dalam operasi. Oleh karena itu keuntungan yang besar tidak menjamin atau bukan merupakan ukuran bahwa dalam perusahaan tersebut dapat melangsungkan hidupnya secara kontinu.

Perusahaan merupakan suatu badan yang melakukan berbagai aktivitas bisnis agar memperoleh laba. Laba perusahaan merupakan sumber modal utama yang menompang kelangsungan hidup perusahaan. Laba perusahaan digunakan untuk membiayai segala aktivitas operasional perusahaan dan investasi perusahaan. Sebagai bagian yang penting bagi perusahaan,penilaian laba merupakan hal yang sangat krasial. Penilaian laba ini bertujuan untuk mengevaluasi perolehaan laba di masa kini dan perkiraan laba di masa depan. Perusahaan merupakaan organisasi bisnis yang bertujuan untuk mendapatkan laba guna menjag a kontinuitas usaha dan perkembangan usaha.

Demi tercapainyaa tujuan tersebut ,perusahaan harus mampu memperoleh dan memanfaatkan sumber-sumber ekonomi yang dimiliki dalam jumlah terbatas,dengan penataan strategi yang tepat. Dalam pendirin perusahaan,tujuan perusahaan adalah memaksimalkan nilai pemegang saham. Nilai pemegang saham akan meningkat apabila nilai perusahaan meningkat yang di tandai dengan tingkat pengembalian investasi yang tinggi pada pemegang saham.

Menurut Taswan dan Soliha (2002),nilai perusahaan yang tinggi menjadi keinginan pemilik perusahaan,sebab dengan nilai perusahaan yang tinggi menunjukan kemakmuran pemegang saham juga tinggi. Untuk mencapai tujuan perusahaan,manajer membuat keputusan investasi yang menghasilkan net present value positif. Menurut Bangun dan Wati (2007),dalam melakukan investasi, investor akan mempertibangkan profit dari perushaan mana yang akan memberikan return tinggi. Profitabilitas memberikan nilai yang objektif mengenai nilai investasi pada sebuah perusahaan. Oleh karena itu profit sebuah perusahaan merupakan harapan bagi investor,tapi investor juga harus berhati-hati dalam menentukan keputusan investasi karena jika tidak tepat ,maka investor tidak hanya kehilangan return tetapi semua modal awal yang di investasikannya juga akan hilang.

Oleh karena itu,investor juga perlu mengumpulkan informasi yang lengkap dan tepat mengenai perusahaan yang akan di pilih sebagai tempat investasinya. Dengan mengelola sumber dana secara efisien ,diharapkan perusahaan dapat meningkatkan keuntungannya. Menurut Irawati (2006:193) menyatakan bahwa "penggunan dari massing-masing jenis modal mempunai pengaruh berbeda terhadap laba yang di peroleh perusahaan". Sedangkan Menurut Aditya (2006:22) menyatakan bahwa "Perusahaan yang memiliki tingkat pengembalian investasi (profitabilitas) tinggi cenderung memiliki hutang dalam jumlah kecil karena 


\section{JURNAL AKUNTANSI, Vol. 7, No. 2, November (2018)}

penggunaan ekuitas (Modal sendiri) lebih besar. Adapun pendapat lain mengnai ini adalah Sartono (1996:296) menyatakan bahwa semakin besar penggunaan hutang dalam modal maka semakin meningkat ROE suatu perusahaan.

Adapun data mengenai profitabilitas pada tahun 2013-2016 pada PT. ABC sebagai berikut

\section{Tabel 1. Laba Pertahun}

\begin{tabular}{|l|l|}
\hline \multicolumn{1}{|c|}{ Tahun } & Laba pertahun \\
\hline 2013 & $(299.237 .029,11)$ \\
\hline 2014 & $1.989 .114 .779,87$ \\
\hline 2015 & $(1.080 .508 .202,93)$ \\
\hline 2016 & $(651.596 .245,63)$ \\
\hline
\end{tabular}

Dari data di atas dapat diketahui bahwa pada tahun 2013 sudah mengalami kerugian hal ini ditimbulakan karena adanya beban bunga yang tinggi di tahun 2013. Pada tahun 2014 mengalami peningkatan sebesar Rp.1.989.114.779,87 dikarenakan adanya penjualan dan pendapatan lain-lain yang naik sehinga pada tahun 2014 meningkat. Sedangkan pada tahun 2014 ke 2015 mengalami penurunan yang cukup besar di karenakan modal yang sedikit dan biaya operasional yang tinggi dan pada tahun berikutnya yaitu pada tahun 2015 ke 2016 juga mengalami penurunan di karenakan laba yang di peroleh perusahaan sedikit sedangkan biaya yang di keluarkan lebih banyak dan membuat laba yang di peroleh tidak sesuai dengan harapan perusahaan.

Berdasarkan uraian di atas maka penulis bertujuan untuk menganalisis pengaruh modal kerja dan biaya operasional terhadap profitabilitas.

\section{KAJIAN LITERATUR \\ Teory Keagenan ( Agency Teory )}

Hubungan keagenan merupakan suatu kontrak antara prinsipal dengan agen. Hubungan keagenan dapat menimbulkan masalah pada saat pihak-pihak yang bersangkutan mempunyai tujuan yang berbeda, pemilik modal meghendaki bertambahnya kekayaan dan kemakmuran para pemilik modal, sedangkan manajer juga menginginkan bertambahnya kesejahteraan bagi para manajer. Dengan demikian muncullah knflik kepentingan antara pemilik (investor) dengan manajer (agen). Pemilik lebih tertarik untuk memaksimumkan kompensassnya. Kontrak yang dibuat antara pemilik dengan manajer diharapkan dapat meminimumkan konflik antar kedua kepentingan tersebut (Setyapurnama dan Norpratiwi 2004).

\section{Modal Kerja}

Kegiatan operasional suatu perusahaan, modal kerja memiliki peranan yang sangat utama sehingga kegiatan dan kehidupan perusahaan tetap berlangsug. Modal kerja menunjukan tingkat keamanan atau margin of safety para kreditur terutama kreditur jangka pendek.

Menurut Soediyono (2005: 160) "Modal kerja merupakan sumber pembiayaan jangka panjang yang khusus membiayai kegiatan perusahaan sehari-hari", Sedangkan menurut Munawir (2014:115) "Modal kerja adalah kelebihan nilai aktiva yang dimiliki perushaan terhadap seluruh hutang-hutangnya". Menurut K.R. Subramanyam dan John J.Wild (2014:241) “ Modal kerja adalaah penjualan bersih selisih aset lancar setelah dikurangi kewajiban lancar". Modal kerja sangatlah penting untuk melihat seberapa banyak modal yang ada untuk membiayai operasional perushaan. Untuk itu perlunya menghitung modal kerja untuk mengetahui modal yang ada di perusahaan. Untuk itu modal kerja mengukur menggunakan model yaitu: 


\section{Biaya Operasional}

Dalam menjalankan aktifitasnya,suatu perusahaan akan mengeluarkan bebagai jenis biaya diantaranya dalah biaya bahan,upah langsung dan biaya overhead dimana ketiga biaya ini di sebut biaya produksi. Biaya lainnya untu kelancaran penjualan atau pemasaran dan administrasi biaya operasional. Biaya operasional menurut Nafirin (2000:76) "Biaya operasional adalah biaya usaha pokok perusahaan selain harga okok penjualan. Biaya usaha terdiri dar biaya pejualan,adminstrasi dan umum."

Biaya operasional atau biasya opersi (operating expense) adalahn biaya-biaya yang tidak berhubungan langsung dengan produk perusahaaan tetapi berkaitan dengan aktivitas operasional perusahaan sehari-hari (Jopie,2008).

Berikut rumus biaya oprasional yaitu :

\begin{tabular}{|c|c|}
\hline \multirow{2}{*}{ Operating ratio $=$} & HPP + Biaya usaha \\
\hline & $\begin{array}{c}\text { Total penjualan } \\
\text { X } 100 \%\end{array}$ \\
\hline
\end{tabular}

\section{Rasio Profitabilitas $\left(X_{3}\right)$}

Rasio profitabilitas merupakan rasio untuk menilai kemampuan dalam mencari keuntungan. Rasio ini juga memberikan ukuran manajemen suatu perusahaan. (Kasmir,2008:196)

Rasio profitabilitas adalah untuk mengukur kemampuan suatu perusahaan menghasilkan laba. (Lukas Setia Atmaja ,2008:417).

Dalam penelitian ini menggunakan rumuas ROE. Berikut rumus profitabilitas dengan menggunakan Ratio yaitu :

\begin{tabular}{|c|c|c|}
\hline \multirow{2}{*}{$\mathrm{ROE}=$} & Laba bersih & \multirow{2}{*}{ X $100 \%$} \\
\hline & Total equity & \\
\hline
\end{tabular}

Hasil penelitian menurut J.E Sutanto dan Yanuar Pribadi pada tahun 2009 menyatakan bahwa Modal kerja berpengaruh positif terhadap profitabilitas, hasil penelitian ini juga konsiisten dengan hasil penelitian oleh Ni Wayan Yulianti pada tahun 2013 yang juga menyatakan hassil penelitiannya yaitu bahwa modal kerja berpengaruh terhadap profitabilitas. Tidak hanya itu pada penelitian sebelumnya oleh Soliha dan Taswan (2002) juga meneliti hasil penelitiannya yang menyatakan bahwa modal kerja berpengaruh positif terhadap profitabilitas. Namun ada beberapa peneliti seperti yoyon Supriadi dan Ratih puspitasari 2012 menyatakan haasil penelitiannya bahwa modal kerja tidak berpengaruh atau berpengaruh negatif terhdap profitabilitas. Hal ini juga setara dengan hasil penelitian oleh Faurani singangerda (2006) yang juhga menyatakan dalam hasil penelitiannya bahwa tidak adanya penagaruh modal kerja terhdap profitabilitas atau hasil negatif. Oleh karena itu hipotesis yang dapat di bangun adalah:

H1 : Modal kerja berpengaruh positif dan signifikan terhadap profitabilitas

Hasil penelitian menurut penelitian terdahulu yaitu oleh Sri wahyu Rasyid 2012 menyatakan hasil penelitiannya bahwa baiaya operasional berpengruh positif dan signifikan terhadap 


\section{JURNAL AKUNTANSI, Vol. 7, No. 2, November (2018)}

profitabilitas. Hasil penelitian itu juga konsisten dengan haasil penelitian oleh Budi Ponco S.T (2008) yang menyatakan bahwa biaya operasional berpeengaruh positif. Namun menurut hasil penelitian oleh Juki 2008 menyatakan hasil penelitiannya tidak perbengaruh atau hassil penelitiaanya negatif. Oleh karena itu hipotesis yang dapat di bangun adalah :

$\mathrm{H} 2$ : Biaya operasional berpengaruh positif dan signifikan terhadap profitabilitas

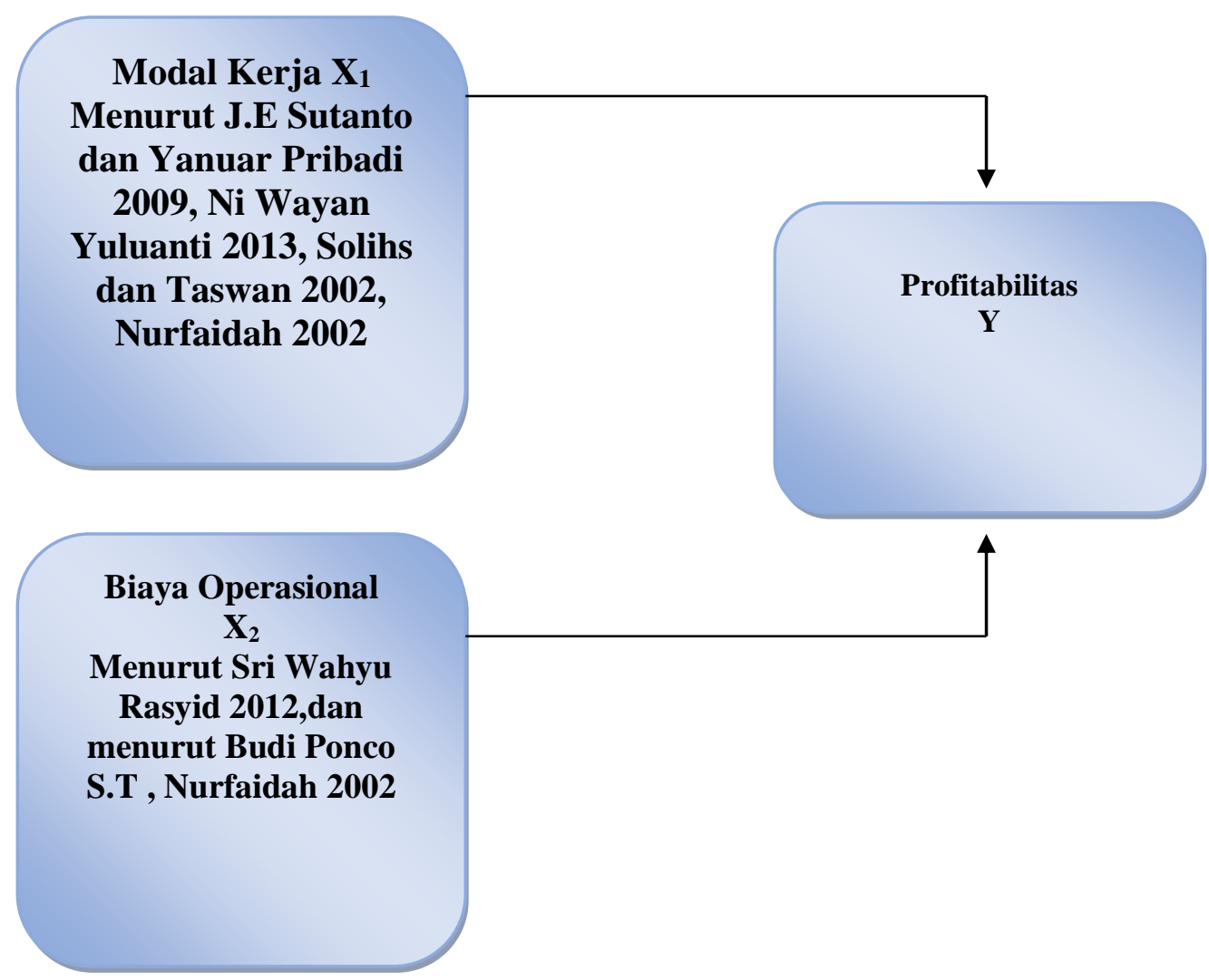

Gambar 2. Kerangka Pikir

\section{METODE PENELITIAN}

Sample dalam penelitian ini adalah PT. Bintang Turbo Indonesia yang berupa data sekunder yaitu laporan keuangan 2013-2016.

$$
\mathrm{Y}=\mathrm{a}+\mathrm{b}_{1}\left(\mathrm{X}_{1}\right)+\mathrm{b}_{2}\left(\mathrm{X}_{2}\right)+\mathrm{e}
$$

Keterangan :

$\mathrm{Y} \quad=$ Profitabilitas yang di ukur berdasarkan ROE

A $\quad=$ Konstanta

b 1 = Koefisien regresi, yaitu besarnya perubahan $\mathrm{Y}$ apabila $\mathrm{X} 1$ berubah sebesar 1 satuan 


\section{JURNAL AKUNTANSI, Vol. 7, No. 2, November (2018)}

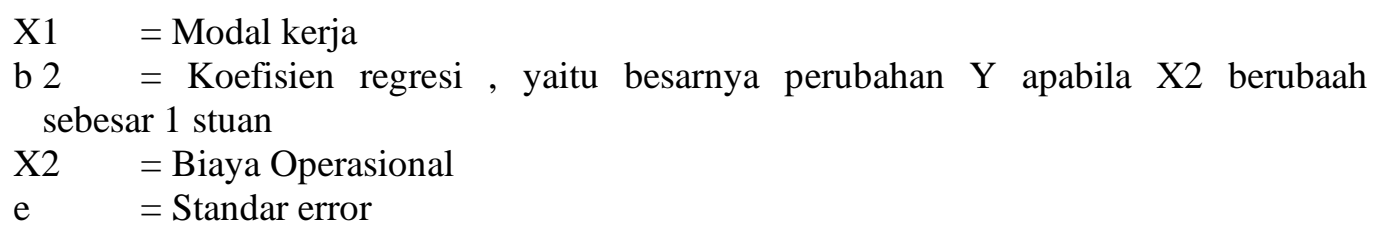

HASIL DAN PEMBAHASAN

Analisis Deskripsi

Descriptive Statistics

\begin{tabular}{|l|l|l|l|}
\hline & Mean & Std. Deviation & $\mathrm{N}$ \\
\hline Profitabilitas & .1004 & .08710 & 48 \\
Modal kerja & .1490 & .18131 & 48 \\
Biaya operasional & 1.3688 & .79526 & 48 \\
\hline
\end{tabular}

Hasil dari uji deskriptif statistik di atas maka dapat di artikan bahwa Profitabilitas atau variabel dependen dengan jumlah data $(\mathrm{N}$ ) yaitu 48 dengan rata rata 0.1004 dan standar deviation 0.08710. begitu juga dengan Modal kerja dimana N 48 dan rata rata 0.1490 dengan standar deviasi 0.18131 . Biaya Operasional dimana $\mathrm{N} 48$ dan jumlah rata-rata 1.3688 dan standar deviasi yaitu 0.79526 .

\section{Analisa Data}

\section{Uji Asumsi Klasik}

Hasil uji asumsi klasik menunjukan bahwa uji normalitas terpenuhi, dengan menggunakan uji statistik non-parametrik Kolmogorov-Smirnov (K-S) yang mana kriteria suatu data residual berdistribusi normal yaitu nilai Asymp. Sig. (2-tailed) >0,05 dan hasil menunjukan bahwa data dalam penelitian ini berdistribusi normal karena nilai nya Kolmogorov-Smirnov $>0.05$ yaitu 0.109. kemudian untuk uji multikolinieritas hasil nya menunjukan bahwa antara variable modal kerja dan biaya operasional tidak berkorelasi atau multikolinieritas tidak terjadi dalam model penelitian karena diperoleh nilai VIF lebih kecil dari 10 yaitu 1.157 untuk modal kerja dan biaya operasional . Hasil uji heteroskedastisitas menunjukan bahwa tidak terjadi heteroskedastisitas karena terlihat pada titik-titik yang menyebar secara acak diatas dan dibawah angka nol (0) dan tidak membentuk suatu pola tertentu, maka dapat dikatakan bahwa regresi tidak mengalami ganguan heteroskedastisitas sehingga model regresi layak dipakai untuk memprediksi kinerja kerja berdasarkan masukan variabel bebas

\section{Gambar 2. Scatterplot Uji}




\section{JURNAL AKUNTANSI, Vol. 7, No. 2, November (2018)}

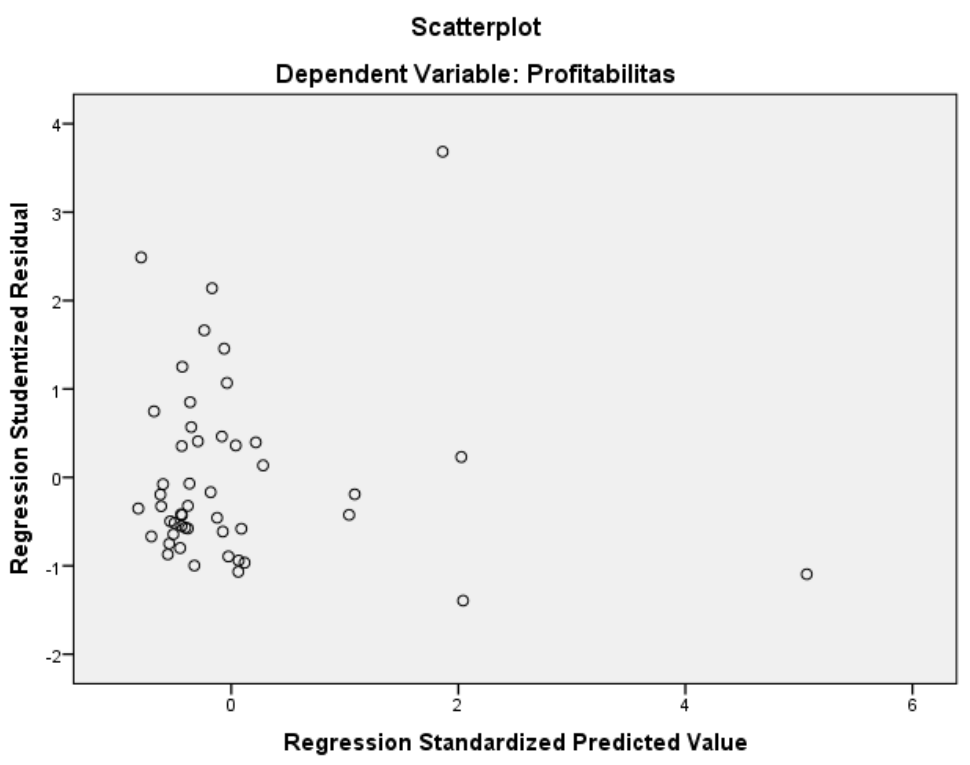

Heteroskedastisitas

Sumber : Data diolah peneliti

\section{Analisis Regresi}

Hasil dari analisa regresi yang dilakukan menunjukan model penelitian sebagai berikut:

$$
\mathrm{Y}=0.048+0.239 \mathrm{X}_{1}+0.013 \mathrm{X}_{2}
$$

Uji statistic $\mathrm{t}$ menunjukan seberapa jauh pengaruh variabel penjelas/independen secara individual dalam menerangkan variasi variabel dependen. Apakah variabel independen berpengaruh secra nyata atau tidak. $\mathrm{H} 0$ diterima dan $\mathrm{H} 1$ di tolak jika nilai $\mathrm{t}$ hitung $<\mathrm{t}$ tabel atau jika nilai sig > 0.05. H0 ditolak dan H1 diterima jika nilai t hitung $>\mathrm{t}$ tabel atau jika nilai sig < 0.05. Berdasarkan modal kerja (X1) t hitung $3.507>\mathrm{t}$ tabel sebesar 2.01410 dan nilai sig $0.001<0.05$. Maka dapat disimpulkan bahwa H0 ditolak dan H1 diterima yang artinya bahwa terdapat pengaruh positif dan sigifikan modal kerja (X1) terhadap Profitabilitas (Y).

Dari tabel di atas juga terdapat hail nilai hasil dari biaya operasional (X2) $\mathrm{t}$ hitung $0.814<\mathrm{t}$ tabel 2.01410 dan nilai sig $0.420>0.05$ maka dapat disimpulkan bahwa H0 diterima dan H1 ditolak, yang artinya tidak terdapat pengaruh secara signifikan biaya operasional (X2) terhadap profitabilitas (Y) . Hal ini dikarenakan biaya operasional yang dikeluarkan perusahaan terlalu tinggi yang mengakibatkan perusahaaan meminjaam modal dari bank untuk membiayai biaya operasional perusahaan. Perusahaan meminjam modal dari bank dikarenakan modal dari persuahaan yang sedikit sehingga perusahaan tidak mampu membiayai biaya operasional yang terlalu tinggi dengan modal sendiri. Untuk itu meski biaya operasional tinggi perusahaan tetap mendapatkan laba. Hal ini dikarenakan adanya pendapatan yang mampu menutupi biaya operasional perusahaan sehingga laba dapat dikendalikan. 
Tabel 3. Hasil Uji Signifikan Koefisien (Uji t)

Coefficients $^{a}$

\begin{tabular}{|c|c|c|c|c|c|c|}
\hline \multirow{2}{*}{\multicolumn{2}{|c|}{ Model }} & \multicolumn{2}{|c|}{ Unstandardized Coefficients } & \multirow{2}{*}{$\begin{array}{c}\begin{array}{c}\text { Standardized } \\
\text { Coefficients }\end{array} \\
\text { Beta }\end{array}$} & \multirow[b]{2}{*}{$t$} & \multirow[b]{2}{*}{ Sig. } \\
\hline & & B & Std. Error & & & \\
\hline \multirow[t]{3}{*}{1} & (Constant) & .048 & .029 & & 1.638 & .108 \\
\hline & Modal kerja & .239 & .068 & .497 & 3.507 & .001 \\
\hline & Biaya operasional & .013 & .016 & .115 & .814 & .420 \\
\hline
\end{tabular}

Persamaan regresi di atas dapat dijelaskan sebagai berikut :

1. Konstanta sebesar 0.048 ; artinya jika modal kerja $\left(\mathrm{X}_{1}\right)$ dan biaya operasional $\left(\mathrm{X}_{2}\right)$ nilainya adalah 0 , maka profitabilitas (Y) nilainya adalah 0.048 .

2. Koefisien regresi variabel modal kerja $\left(\mathrm{X}_{1}\right)$ sebesar 0.239 ; artinya jika variabel independen lain nilainya tetap dan modal kerja mengalami kenaikan $1 \%$, maka profitabilitas (Y) akan mengalami kenaikan sebesar 0.239 . Koefisien bernilai positif artinya terjaadi hubungan positif antara modal kerja dengan profitabilitas, semakin naik modal kerja maka semakin naik profitabilitas.

3. Koefisien regresi variabel biaya operasional $\left(\mathrm{X}_{2}\right)$ sebesar 0.013 ; artinya jika variabel independen lain tetap dan biaya operasional mengaalami kenaikan $1 \%$ maka profitabilitas mengalami peningkatan sebesar 0.013 . Koefisien bernilai positif artinya terjadi hubungan positif antara biaya operasional engan profitabilitas, semakin naik biaya operasional semakin meningkat profitabilitas.

\section{Uji Simultan (Uji F)}

Dari hasil uji anova atau F-test menunjukan F hitung sebesar $6.282>\mathrm{F}$ tabel 3.20 dan nilai dari sig 0.004 maka lebih kecil dari 0.05 . Hal ini menunjukan bahwa hasil dari uji $\mathrm{f}$ ini menunjukan bahwa terdapat pengaruh antara variabel independen terhadap variabel dependen secara signifikan. Sehingga dapat di simpulkan bahwa modal kerja dan biaya operasional berpengaruh signifikan terhadap profitabilitas.

\section{Tabel 4. Koefisien Determinasi}

\begin{tabular}{|c|c|c|c|c|c|c|c|}
\hline \multirow[b]{3}{*}{ Model } & & & & Summary & & & \\
\hline & \multirow[b]{2}{*}{$\mathrm{R}$} & \multirow[b]{2}{*}{ R Square } & \multirow[b]{2}{*}{$\begin{array}{l}\text { Adjusted R } \\
\text { Square }\end{array}$} & \multirow[b]{2}{*}{$\begin{array}{l}\text { Std. Error of } \\
\text { the Estimate }\end{array}$} & \multicolumn{3}{|c|}{ Change Statistics } \\
\hline & & & & & $\begin{array}{c}\text { R Square } \\
\text { Change }\end{array}$ & F Change & df1 \\
\hline 1 & $.467^{\mathrm{a}}$ & .218 & .184 & .07871 & .218 & 6.282 & 2 \\
\hline
\end{tabular}

Model Summary ${ }^{b}$

\begin{tabular}{|l|r|r|c|}
\hline \multirow{2}{*}{ Model } & \multicolumn{2}{|c|}{ Change Statistics } & \multirow{2}{*}{$\begin{array}{c}\text { Durbin- } \\
\text { Watson }\end{array}$} \\
\hline 1 & df2 & Sig. F Change & 2.008 \\
\hline
\end{tabular}

a. Predictors: (Constant), Biaya operasional, Modal kerja

b. Dependent Variable: Profitabilitas

Koefisien determinasi Adjusted R square di atas dapat di jelaskan sebagai berikut :

Dari output model summary, diketahui nilai koefisien determinasi adjusted $\mathrm{R}$ square sebesar 0.184. Besarnya angka koefsien determinasi adjusted $\mathrm{R}$ square 0.184 sama dengan 18,4 \%. 


\section{JURNAL AKUNTANSI, Vol. 7, No. 2, November (2018)}

Angka tersebut mengandung anrti bahwa modal kerja dan biaya operasional berpengaruh terhadap profitabilitas sebesar 18,4\%. Sedangkan $(100 \%-18,4 \%=81,6 \%)$ di pengaruhi oleh variabel lain di luar model regresi ini. Bersama pengaruh variabel lain ini sering disebut sebagai error (e). Untuk menghitung nilai eror dapat digunakan rumus e $=1-\mathrm{R} 2$. Sebagai catatan, besarnya nilai koefisien determinasi atau R square hanya antara $0-1$.

Sementara jika dijumpai R Square bernila minus ( - ), maka dapat dikatakan bahwa tidak terdapat X terhadap Y. Semakin kecil nilai koefisien determinasi adjusted R Square, maka ini artinya pengaruh variabel bebas terhadap variabel terikat semakin lemah. Sebaliknya, jika nilai adjusted $\mathrm{R}$ Square semakin mendekati 1, maka pengaruh tersebut akan semakin kuat. Namun hasil summary pada metode determinasi adjusted R square hanya 0.184 .

\section{PENUTUP}

Berdasarkan pembahasan maka dapat disimpulkan bahwa secara parsial terdapat pengaruh yang signifikan anatara modal kerja terhadap profitabilitas di perusahaan PT.Bintang Turbo Indonesia. Secara parsial tidak terdapat pengaruh antara biaya operasional terhadap profitabilitas pada PT.Bintang Turbo Indonesia. Hal ini dikarenakan biaya operasional yang dikeluarkan perusahaan terlalu tinggi yang mengakibatkan perusahaaan meminjaam modal dari bank untuk membiayai biaya operasional perusahaan. Perusahaan meminjam modal dari bank dikarenakan modal dari persuahaan yang sedikit sehingga perusahaan tidak mampu membiayai biaya operasional yang terlalu tinggi dengan modal sendiri. Untuk itu meski biaya operasional tinggi perusahaan tetap mendapatkan laba. Hal ini dikarenakan adanya pendapatan yang mampu menutupi biaya operasional perusahaan sehingga laba dapat dikendalikan. Secara bersama-sama atau secara simultan terdapat pengaruh anatara modal kerja dan biaya operasional terhadap profitabilitas pada PT.Bintang Turbo Indonesia.

Berdasarkan kesimpulan yang ada, peneliti memberikan saran pada pihak manajemen perusahaan hendaknya meningkatkan efisiensi modal kerjanya. Karena apabila modal kerja dalam perushaan menunjukan tingkat efesiensi yang tinggi stabil maka seiring dengan peningkatan yang efisien juga akan berpengaruh terhadap tingkat profitabilitas dan pihhak manajemen perusahaan seharusnya harus lebih memperhatikan biaya-biaya yang dikeluarkan sehingga dapat mencegah ledakan biaya-biaya yang tidak terduga karena hal ini yang nantinya akan mempengaruhi profitabilitas perusahaan.

\section{REFERENSI}

Abrams, Rhonda, Alice Laplante, Kusnandar ( Penterjemah ) 2010. Passion to Profits: Cetakan 1. Tanggeang: Azkia Publisher : Kelompok Pustaka Alvabet.

Atmaja,Lukas Setia.2008. Manajemen Keuangan. Buku I, Penerbit Andi, Yogyakarta.

Aditya, Januarino. 2006. Studi Empiris Faktor-faktor yang Mempengaruhi Struktur Modal pada Perusahaan Manufaktur di Bursa Efek Jakarta Periode Tahun 2000-2003. Skripsi Universitas Islam Indonesia : Yogyakarta.

Agus R Sartono. (1996). Manajemen Keuangan, Teori dan Aplikasi, Yogyakarta : BPFE

Bangun, Nurainun. Dan Wati, S,. 2007. Analisis Pengaruh Profitabilitas dan Kebijakan Dividen Terhadap Nilai Perusahaan Perdagangan, Jasa, dan Investasi yang Terdaftar di Bursa Efek Jakarta., Jurnal Akuntansi/Tahun XI, No.02 : 107-120.

Ghozali Imam. 2001. Aplikasi Analisis Multivariate Dengan Program SPSS, Badan peneliti Universitas Diponegoro,Semarang.

Ghozali,Imam. 2005. Aplikasi Analisis Multivariate dengan Program SPSS, Edisi Ketiga, Badan Peneliti Universitas Diponegoro, Semarang. 
Hanafi, M Mahmud dan Abdul Halim, 2005. Analisi laporan Keuangan, Yogyakarta: AMP, YKPN

Jensen, Michael C dan William H. Meckling. 1976. Theory of the firm: Managerial Behavior, Agency Costs and Ownership Structure. Journal of Financial Ekonomis. Vol.3, No.4,Hal.305-360.

Jopie, jusuf. 2008. Aanalisis kredit untuk Account Officer. Pt Gramedia.

Jusuf, Jopie. 2007. Analisis Kredit Untuk Account Officer: Cetakan ke 8. Jakarta: PT. Gramedia Pustaka Utama.

Juki, Umar, 2008. "Pengaruh Biaya Operasional terhadap Profitabilitas pada PT Kereta Api Indonesia (Persero)".

Kasmir. 2008. Analisa Laporan Keuangan Jakarta . Jakarta : Rajawali Pers.

Kasmir. 2010. Dasar-dasar Perbankan. Jakarta. PT Raja Grafindo Persada.

M. Nafirin. 2000. Pengganggaran Perusahaan. Penerbit: Salemba Empat, Jakarta.

Munawir. 2002. Analisis Laporan Keuangan . Liberty, Yogyakarta.

Munawir . 2004. Analisis Laporan Keuangan, Yogyakarta: Liberty.

Munawir. 2007. Analisa laporan keuangan. Liberty, Yogyakarta.

Munawir. 2014. Analisa Laporan Keuangan. Yogyakarta: Liberty.

Mulyadi . 2000 . Akuntansi Biaya Edisi 5 . Yogyakarta : Aditya Media.

Mulyadi. 2003. Activity Based Cost System-System Informasi Biaya untuk Pengurangan Biaya edisi ke 6. Yogyakarta: UPP AMP YKPN.

Pierre. 2010. The Relationship Between Working Capital Management and Profitability For South African Listed Industrial Firms. The Business Review, Cambridge. 15 (1). Pp. 193-198.

Soliha, E., dan Taswan. 2002. "Pengaruh Kebijakan Hutang Terhadap Nilai Perusahaan Serta Beberapa Faktor Yang Mempengaruhinya". Jurnal Bisnis dan Ekonomi. September 2002

Setyapurnama dan Norpratiwi. 2004. "Pengaruh Corporate Governance terhadap peringkat Obligasi dan Yield Obligasi." www.google.com

Subramanyam,K.R an John J. Wild. 2014. Buku 2. Edisi 10. Analisis Laporan Keuangan, Jakarta: Salemba Empat.

Sugiyono.2006. Metode Penelitian Kuantitatif Kualitatif dan R\&D. Bandung : Alfabeta.

Sugiyono. 2009. Metode Penelitian Bisnis. Bandung: Alfabeta

Uma Sekaran. 2009. Researh Methods For Business (Metodologi Penelitian untuk Bisnis). Jakarta : Salemba Empat.

Westo J.Fred dan Eugene F.Brigham. 2001. Dasar-Dasar Manajemen Keuangan , Erlangga: Jakarta.

Wild, Subramanyam dan Halsey. 2005 . Analisis Laporan Keuangan . Edisi 8,Salemba Empat. Jakarta.

Yoyon Supriadi dan Ratih Puspitasari, 2012, Pengaruh Modal Kerja Terhadap Penjualan dan Profitabilitas Perusahaan Pada PT. Indocement Tunggal Prakarsa, Tbk (Effect of Working Capital to Sales and Profitability), Dosen STIE Kesatuan, Jurnal I lmiah Kesatuan Nomor 1 Volume 14, April 2012 